\title{
Synthesis and Characterization of Fluorinated Aminoalkoxide and Iminoalkoxide Gallium Complexes: Application in Chemical Vapor Deposition of $\mathrm{Ga}_{2} \mathrm{O}_{3}$ Thin Films
}

\author{
Yun Chi, ${ }^{* \dagger}$ T Tsung-Yi Chou, Yi-J en Wang, and Shu-Fen Huang \\ Department of Chemistry, National Tsing Hua University, \\ Hsinchu 30013, Taiwan, Republic of China \\ Arthur J . Carty,* Ludmila Scoles, and Konstantin A. Udachin \\ Steacie Institute for Molecular Sciences, National Research Council of Canada, \\ 100 Sussex Drive, Ottawa, Ontario K1A 0R6, Canada \\ Shie-Ming Peng and Gene-Hsiang Lee \\ Department of Chemistry and Instrumentation Center, National Taiwan University, \\ Taipe 107, Taiwan, Republic of China
}

Recei ved September 2, 2003

\begin{abstract}
Gallium trichloride, $\mathrm{GaCl}_{3}$, reacts with the in situ prepared sodium salt of an aminoalkoxide or iminoalkoxide, denoted as $\mathrm{NaL}$, to give the disubstituted compounds $\mathrm{GaL}_{2} \mathrm{Cl}$, where $\mathrm{L}=$ $\mathrm{OC}\left(\mathrm{CF}_{3}\right)_{2} \mathrm{CH}_{2} \mathrm{NMe}_{2}$ (1), $\mathrm{OC}\left(\mathrm{CF}_{3}\right)_{2} \mathrm{CH}_{2} \mathrm{C}(\mathrm{Me})=\mathrm{NMe}$ (2). Single-crystal X-ray diffraction studies on $\mathbf{1}$ and $\mathbf{2}$ indicated the formation of a trigonal-bipyramidal structure with chloride and alkoxy groups occupying the equatorial sites and the nitrogen donors located at the axial positions. F or the related trimethylgallium reagent $\mathrm{GaMe}_{3}$, addition of an equal amount of amino al cohol $\mathrm{LH}$ induced the elimination of methane to afford the complexes $\mathrm{GaMe}_{2} \mathrm{~L}$, where $\mathrm{L}=\mathrm{OC}\left(\mathrm{CF}_{3}\right)_{2} \mathrm{CH}_{2} \mathrm{NHMe}(3), \mathrm{OC}\left(\mathrm{CF}_{3}\right)_{2} \mathrm{CH}_{2} \mathrm{NHBu}^{\mathrm{t}}(\mathbf{4}), \mathrm{OC}\left(\mathrm{CF}_{3}\right)_{2} \mathrm{CH}_{2} \mathrm{NMe}_{2}$ (5), in high yields. The crystal structure of $\mathbf{5}$ was determined by X-ray diffraction, showing a distortedtetrahedral framework which differs greatly from that observed in the trigonal-bipyramidal Ga complexes $\mathbf{1}$ and $\mathbf{2}$. Variable-temperature ${ }^{1} \mathrm{H}$ NMR studies on $\mathbf{3}$ and $\mathbf{4}$ indicated the occurrence of rapid $\mathrm{N} \rightarrow \mathrm{Ga}$ bond scission, followed by recoordination with a change of the absolute configuration. A lower activation barrier was observed for the $\mathrm{Bu}^{\mathrm{t}}$ complex $\mathbf{4}$ upon changing solvents from $\mathrm{CDCl}_{3}$ to more polar media such as deuterated toluene and THF. Complexes $\mathbf{1}$ and $\mathbf{4}$ were then evaluated as potential precursor molecules for the chemical vapor deposition of $\mathrm{Ga}_{2} \mathrm{O}_{3}$, and the as-deposited films were analyzed using scanning el ectron micrographs (SEM), X-ray photoel ectron spectroscopy (XPS), and Rutherford backscattering (RBS).
\end{abstract}

The synthesis of gallium alkoxide and alkoxidecontaining gallium complexes has been of considerable current interest, due to their potential as molecular precursors for the preparation of gallium oxide $\left(\mathrm{Ga}_{2} \mathrm{O}_{3}\right)$ thin films employing metal organic chemical vapor deposition (MOCVD) techniques. ${ }^{1}$ Tris(alkoxide)gallium complexes are reported to exist as tetramers in solution, according to molecular weight determinations, and conversion to the more favorable dimer structure [Ga$\left.(\mathrm{OR})_{2}(\mu-\mathrm{OR})\right]_{2}(\mathrm{R}=\mathrm{Me}, \mathrm{Et}, \mathrm{Pr}, \mathrm{Bu})$ has been documented upon increasing the size of the alkyl substituents. ${ }^{2}$ It has also been noted that the formation of bridging alkoxide ligands effectively reduces the electron deficiency at the gallium metal center and stabilizes both

\footnotetext{
† Fax: (886) 3 572-0864. E-mail: ychi@mx.nthu.edu.tw.

(1) (a) Valet, M.; Hoffman, D. M. Chem. Mater. 2001, 13, 2135. (b) Kim, D. H.; Yoo, S. H.; Chung, T.-M.; An, K.-S.; Yoo, H.-S.; Kim, Y. Bull. Korean Chem. Soc. 2002, 23, 225.

(2) (a) Bindal, S. R.; Mathur, V. K.; Mehrotra, R. C. J . Chem. Soc. 1969, 863. (b) Oliver, J . G.; Worrall, I. J . J . Chem. Soc. A 1970, 845.
}

tetramer and dimer formation. Unfortunately, dimer or higher oligomer formation results in lower volatility, thus making these molecules less suitable as CVD source reagents. To reduce unwanted self-aggregation observed in these alkoxide complexes, H offman and coworkers attempted the synthesis of amine adducts of fluoroalkoxide compounds with the formula $\mathrm{Ga}\left(\mathrm{OR}_{\mathrm{f}}\right)_{3^{-}}$ $\left(\mathrm{HNMe}_{2}\right), \mathrm{R}_{\mathrm{f}}=\mathrm{CH}\left(\mathrm{CF}_{3}\right)_{2}, \mathrm{CMe}_{2}\left(\mathrm{CF}_{3}\right), \mathrm{CMe}_{2}\left(\mathrm{CF}_{3}\right)_{2}$, and then conducted the preparation of $\mathrm{Ga}_{2} \mathrm{O}_{3}$ thin films using a low-pressure CVD process. ${ }^{3}$ Their studies have showed that these fluorinated alkoxide derivatives not only possess enhanced volatility and stability but are also capable of depositing the desired oxide thin films containing very low levels of fluorine contamination.

Herein, we describe the synthesis of several new gallium fluoroalkoxide complexes, using our recently developed amino alcohol and imino alcohol ligands, ${ }^{4}$ of

(3) Miinea, L.; Suh, S.; Bott, S. G.; Liu, J .-R.; Chu, W.-K.; Hoffman, D. M. J . Mater. Chem. 1999, 9, 929. 
the general structural formula<smiles>[R]N([R])CC(O)(C(F)(F)F)C(F)(F)F</smiles>

aminoalcohol<smiles>O=[W]/C(CC(O)([18F])C(F)(F)F)=N/O</smiles>

iminoalcohol
We hypothesized that the introduction of an amino or imino substituent into the fluoro alcohol ligands would lead to interesting changes in structure and reactivity due to the formation of additional $\mathrm{N} \rightarrow \mathrm{G}$ a dative bonding as compared to the simple parent, fluoro al cohol ligands, and anticipated that the resulting complexes would possess distinct structural properties and enhanced stability due to formation of the chelate interaction. ${ }^{5}$ These features together with low-pressure CVD studies on the newly prepared gallium complexes are described in this paper.

\section{Experimental Section}

General Information and Materials. Mass spectra were obtained on a J EOL SX-102A instrument operating in the electron impact $(\mathrm{EI})$ or chemical ionization $(\mathrm{Cl})$ mode. ${ }^{1 \mathrm{H}},{ }^{13} \mathrm{C}$, and ${ }^{19} \mathrm{~F}$ NMR spectra were recorded on Varian Mercury-400 and I NOVA-500 instruments; chemical shifts are quoted with respect to tetramethylsilane for ${ }^{1} \mathrm{H}$ and ${ }^{13} \mathrm{C}$ NMR data and $\mathrm{CF}_{3} \mathrm{Cl}$ for ${ }^{19} \mathrm{~F} \mathrm{NMR}$ data, respectively. The thermogravimetric analyses (TGA) were recorded on a Seiko TG/DTA 300 instrument under atmospheric pressure of $\mathrm{N}_{2}$ with a flow rate of $100 \mathrm{sccm}$ and with a heating rate of $10{ }^{\circ} \mathrm{C} / \mathrm{min}$. Elemental analyses were carried out at the NSC Regional Instrumentation Center at National Chiao Tung University, Hsinchu, Taiwan. All reactions were performed under an inert atmosphere using commercially available, anhydrous solvents or solvents treated with appropriate drying reagents. The $\mathrm{CF}_{3}{ }^{-}$ substituted amino alcohol ligands of formula $\mathrm{HOC}\left(\mathrm{CF}_{3}\right)_{2} \mathrm{CH}_{2-}$ $\mathrm{NMe}_{2}$ and $\mathrm{HOC}\left(\mathrm{CF}_{3}\right)_{2} \mathrm{CH}_{2} \mathrm{NHR}, \mathrm{R}=\mathrm{Me}, \mathrm{Bu}^{\mathrm{t}}$, were prepared according to the literature method, ${ }^{6}$ while the corresponding imino alcohol ligand $\mathrm{LH}=\mathrm{HOC}\left(\mathrm{CF}_{3}\right)_{2} \mathrm{CH}_{2} \mathrm{C}(\mathrm{Me})=\mathrm{NMe}$ was obtained via direct condensation of the keto al cohol $\mathrm{HOC}\left(\mathrm{CF}_{3}\right)_{2-}$ $\mathrm{CH}_{2} \mathrm{C}(\mathrm{Me})=\mathrm{O}$ with excess methylamine in the presence of montmorillonite $\mathrm{K} 10 .{ }^{4}$

For the study of the surface morphology of the as-deposited thin films, scanning el ectron microscopy (SEM) was recorded on a Hitachi S-4000 system. Before each experiment, the samples were placed on a stage and a gold coating was deposited with a Cressington Sputter-Coater 108 at 0.06-0.08 mbar for $45 \mathrm{~s}$ prior to SEM analyses. The composition of the thin film was determined by X-ray photoelectron spectroscopy (XPS) utilizing a Physical Electronics PHI 1600 system with an $\mathrm{Al} / \mathrm{Mg}$ dual-anode $\mathrm{X}$-ray source. The surface analysis was determined by collecting XPS spectra after $\sim 1$ min sputtering with argon at $4 \mathrm{keV}$ until a constant composition was obtained. Rutherford backscattering spectra were acquired at the Nud ear Science and Technology Development Center (NSTDC) on a Van de Graaff accelerator (Model KN-1008) using a 2-3 MeV ${ }^{4} \mathrm{He}^{+}$beam; the NSTDC is located on the campus of National

(4) (a) Liu, Y.-H.; Cheng, Y.-C.; Tung, Y.-L.; Chi, Y.; Chen, Y.-L. Liu, C.-S.; Peng, S.-M.; Lee, G.-H. J . Mater. Chem. 2003, 13, 135. (b) Lai, Y.-H.; Chou, T.-Y.; Song, Y.-H.; Liu, C.-S.; Chi, Y.; Carty, A. J .; Peng, S.-M.; Lee, G.-H. Chem. Mater. 2003, 15, 2454.

(5) (a) Gruter, G.-J . M.; van Klink, G. P. M.; Akkerman, O. S.; Bickelhaupt, F. Chem. Rev. 1995, 95, 2405. (b) J utzi, P.; Redeker, T. Eur. J . Inorg. Chem. 1998, 663.

(6) (a) Chang, I.-S.; Willis, C. J . Can. J . Chem. 1977, 55, 2465. (b) Loeb, S. J .; Richardson, J . F.; Willis, C. J . Inorg. Chem. 1983, 22, 2736.
Tsing Hua University, Hsinchu, Taiwan. The data were then analyzed using the simulation program RUMP. ${ }^{7}$

Synthesis of 1 . Sodium hydride $(0.146 \mathrm{~g}, 6.1 \mathrm{mmol})$ was suspended in $25 \mathrm{~mL}$ of THF. To this was added dropwise 0.91 $\mathrm{g}$ of the amino alcohol $\mathrm{HOC}\left(\mathrm{CF}_{3}\right)_{2} \mathrm{CH}_{2} \mathrm{NMe}_{2}(4.1 \mathrm{mmol})$ in THF $(25 \mathrm{~mL})$. The mixture was further stirred for $30 \mathrm{~min}$ until evolution of gas had ceased. The solution was filtered to remove the unreacted $\mathrm{NaH}$. The filtrate was then transferred into a $100 \mathrm{~mL}$ reaction flask containing a suspension of $\mathrm{GaCl}_{3}$ $(0.32 \mathrm{~g}, 1.84 \mathrm{mmol})$ in THF solution $(25 \mathrm{~mL})$. This mixture was stirred at room temperature for $4 \mathrm{~h}$, during which time an off-white $\mathrm{NaCl}$ precipitate was gradually produced. The precipitate was removed by filtration under nitrogen, the filtrate concentrated to dryness, and the residue sublimed in vacuo $\left(500 \mathrm{mT}\right.$ orr, $60^{\circ} \mathrm{C}$ ), giving $0.61 \mathrm{~g}$ of the col orless material $\mathrm{Ga}\left[\mathrm{OC}\left(\mathrm{CF}_{3}\right)_{2} \mathrm{CH}_{2} \mathrm{NMe}_{2}\right]_{2} \mathrm{Cl}(\mathbf{1} ; 1.1 \mathrm{mmol}, 60 \%) ; \mathrm{mp} 144{ }^{\circ} \mathrm{C}$. Single crystals suitable for X-ray diffraction study were obtained by cooling a supersaturated hexane solution at room temperature.

Spectral data of $\mathbf{1}$ are as follows. MS (EI): $\mathrm{m} / \mathrm{z} 517\left\{\mathrm{M}^{+}\right.$ $\mathrm{Cl}\} .{ }^{1} \mathrm{H}$ NMR $\left(400 \mathrm{MHz}, \mathrm{C}_{6} \mathrm{D}_{6}, 298 \mathrm{~K}\right): \delta 2.50\left(\mathrm{~d}, \mathrm{CH}_{2},{ }^{2} \mathrm{~J}\right.$ нн $=$ $14.6 \mathrm{~Hz}, 2 \mathrm{H}), 2.18\left(\mathrm{~d}, \mathrm{CH}_{2},{ }^{2} \mathrm{~J} \mathrm{Hн}=14.6 \mathrm{~Hz}, 2 \mathrm{H}\right), 2.05(\mathrm{~s}, \mathrm{NMe}$, $6 \mathrm{H}), 2.04(\mathrm{~s}, \mathrm{NMe}, 6 \mathrm{H}) .{ }^{13} \mathrm{C} \mathrm{NMR}\left(125 \mathrm{MHz}, \mathrm{C}_{6} \mathrm{D}_{6}, 298 \mathrm{~K}\right): \delta$ $124.4\left(\mathrm{q}, \mathrm{CF}_{3},{ }^{1} \mathrm{~J}_{\mathrm{CF}}=290 \mathrm{~Hz}, 2 \mathrm{C}\right), 124.3\left(\mathrm{q}, \mathrm{CF}_{3},{ }^{1} \mathrm{~J} \mathrm{CF}=290\right.$ $\mathrm{Hz}, 2 \mathrm{C}), 75.9\left(\mathrm{~m}, \mathrm{C}\left(\mathrm{CF}_{3}\right)_{2},{ }^{2} \mathrm{I} \mathrm{CF}=28.7 \mathrm{~Hz}, 2 \mathrm{C}\right), 56.7\left(\mathrm{~s}, \mathrm{CH}_{2}\right.$ 2C), 48.5 (s, NMe, 2C), 48.4 (s, NMe, 2C). ${ }^{19} \mathrm{~F}$ NMR $(470.3 \mathrm{MHz}$ $\left.\mathrm{C}_{6} \mathrm{D}_{6}, 298 \mathrm{~K}\right): \delta-76.83\left(\mathrm{q}, \mathrm{CF}_{3},{ }^{4} \mathrm{JF}=11.9 \mathrm{~Hz}\right),-78.20(\mathrm{q}$, $\mathrm{CF}_{3},{ }^{4} \mathrm{JF}=11.9 \mathrm{~Hz}$ ). Anal. Calcd for $\mathrm{C}_{12} \mathrm{H}_{16} \mathrm{ClF}_{12} \mathrm{GaN}_{2} \mathrm{O}_{2}: \mathrm{C}$, 26.04; H, 2.91; N, 5.05. Found: C, 26.07; H, 2.97; N, 5.06.

Synthesis of 2. Sodium hydride $(0.146 \mathrm{~g}, 6.1 \mathrm{mmol})$ was first suspended in $25 \mathrm{~mL}$ of THF. To this was added dropwise $0.96 \mathrm{~g}$ of the imino alcohol ligand $\mathrm{LH}=\mathrm{HOC}\left(\mathrm{CF}_{3}\right)_{2} \mathrm{CH}_{2} \mathrm{C}(\mathrm{Me})=$ $\mathrm{NMe}(4.1 \mathrm{mmol})$ in THF $(25 \mathrm{~mL})$, and the mixture was stirred for 30 min until evolution of gas had ceased. The solution was filtered to remove the unreacted $\mathrm{NaH}$. The filtrate was then transferred into a $100 \mathrm{~mL}$ flask containing a suspension of $\mathrm{GaCl}_{3}(0.32 \mathrm{~g}, 1.84 \mathrm{mmol})$ in THF solution $(25 \mathrm{~mL})$. This mixture was stirred at room temperature for $4 \mathrm{~h}$, during which time an off-white $\mathrm{NaCl}$ precipitate was gradually produced. The precipitate was filtered and the filtrate concentrated to dryness and vacuum sublimed (500 mTorr, $75^{\circ} \mathrm{C}$ ), giving $0.77 \mathrm{~g}$ of the air-sensitive, colorless material $\mathrm{Ga}\left[\mathrm{OC}\left(\mathrm{CF}_{3}\right)_{2^{-}}\right.$ $\mathrm{CH}_{2} \mathrm{C}(\mathrm{Me})=\mathrm{NMel}{ }_{2} \mathrm{Cl}(2 ; 1.33 \mathrm{mmol}, 72 \%) ; \mathrm{mp} 136{ }^{\circ} \mathrm{C}$. Single crystals suitable for an X-ray diffraction study were obtained via sublimation at reduced pressure in a sealed tube.

Spectral data of $\mathbf{2}$ are as follows. MS (EI): $\mathrm{m} / \mathrm{z} 576\left\{\mathrm{M}^{+}\right\}$. ${ }^{1} \mathrm{H}$ NMR $\left(400 \mathrm{MHz}, \mathrm{C}_{6} \mathrm{D}_{6}, 298 \mathrm{~K}\right): \delta 2.91(\mathrm{~s}, \mathrm{NMe}, 6 \mathrm{H}), 2.64$ $\left(\mathrm{d}, \mathrm{CH}_{2},{ }^{2} \mathrm{H} \mathrm{HH}=16.0 \mathrm{~Hz}, 2 \mathrm{H}\right), 2.40\left(\mathrm{~d}, \mathrm{CH}_{2},{ }^{2} \mathrm{~J} \mathrm{Hн}=16.0 \mathrm{~Hz}\right.$, $2 \mathrm{H}), 0.93$ (s, CMe, 6H). ${ }^{13} \mathrm{C}$ NMR (125 MHz, $\left.\mathrm{C}_{6} \mathrm{D}_{6}, 298 \mathrm{~K}\right): \delta$ 175.7 (s, CN, 2C), 124.4 (q, $\left.\mathrm{CF}_{3},{ }^{1} \mathrm{~J} \mathrm{CF}=290 \mathrm{~Hz}, 2 \mathrm{C}\right), 124.3$ (q, $\left.\mathrm{CF}_{3},{ }^{1} \mathrm{~J} \mathrm{CF}=290 \mathrm{~Hz}, 2 \mathrm{C}\right), 78.8\left(\mathrm{~m}_{1} \mathrm{C}\left(\mathrm{CF}_{3}\right)_{2},{ }^{2} \mathrm{~J}_{\mathrm{CF}}=28.7 \mathrm{~Hz}, 2 \mathrm{C}\right)$, $38.4(\mathrm{~s}, \mathrm{NMe}, 2 \mathrm{C}), 36.2\left(\mathrm{~s}, \mathrm{CH}_{2}, 2 \mathrm{C}\right), 21.6\left(\mathrm{~s}, \mathrm{CH}_{3}, 2 \mathrm{C}\right) .{ }^{19} \mathrm{~F} \mathrm{NMR}$ $\left(470.3 \mathrm{MHz}, \mathrm{C}_{6} \mathrm{D}_{6}, 298 \mathrm{~K}\right): \delta-77.31\left(\mathrm{q}, \mathrm{CF}_{3}, 4 \mathrm{~J}_{\mathrm{FF}}=8.6 \mathrm{~Hz}\right.$, $6 F),-78.60\left(q, \mathrm{CF}_{3},{ }^{4} \mathrm{FF}=8.6 \mathrm{~Hz}, 6 \mathrm{~F}\right)$. Anal. Calcd for $\mathrm{C}_{12} \mathrm{H}_{16}$ $\mathrm{ClF}_{12} \mathrm{GaN}_{2} \mathrm{O}_{2}$ : C, 29.12; $\mathrm{H}, 2.79 ; \mathrm{N}, 4.85$. Found: $\mathrm{C}, 28.76 ; \mathrm{H}$, 3.18; N, 5.14

Synthesis of 3. A $50 \mathrm{~mL}$ flask was charged with trimethylgallium $(0.35 \mathrm{~g}, 3 \mathrm{mmol})$ and $20 \mathrm{~mL}$ of diethyl ether. The amino alcohol ligand $\mathrm{HOC}\left(\mathrm{CF}_{3}\right)_{2} \mathrm{CH}_{2} \mathrm{NHMe}(0.63 \mathrm{~g}, 3 \mathrm{mmol})$ was then added dropwise to this solution at $0{ }^{\circ} \mathrm{C}$ over a period of $1 \mathrm{~h}$. The resulting solution was stirred for an additional $2 \mathrm{~h}$ at room temperature to ensure the completion of the reaction. Solvent was removed under vacuum, and the residue was sublimed at $60{ }^{\circ} \mathrm{C}$ and 650 mTorr. Recrystallization from a mixture of $\mathrm{CH}_{2} \mathrm{Cl}_{2}$ and hexane afforded a crystalline solid [GaMe $\left.2\left(\mathrm{OC}\left(\mathrm{CF}_{3}\right)_{2} \mathrm{CH}_{2} \mathrm{NHMe}\right)\right]$ (3; $782 \mathrm{mg}, 2.5 \mathrm{mmol}$ ) in $84 \%$ yield; $\mathrm{mp} 95^{\circ} \mathrm{C}$.

Spectral data of 3 are as follows. MS (Cl): m/z $294\left\{\mathrm{M}^{+}\right.$ Me\}. ${ }^{1} \mathrm{H}$ NMR $\left(400 \mathrm{MHz}, \mathrm{CDCl}_{3}, 298 \mathrm{~K}\right): \delta 3.43\left(\mathrm{dd}, 1 \mathrm{H}, \mathrm{NCH}_{2}\right.$,

(7) Thompson, M. O. RUMP, version 4.00 (beta); Computer Graphic Service, Ltd., EI Paso, TX, 2002. 
Table 1. Crystal Data and Structure Refinement Parameters for Complexes 1, 2, and 5

\begin{tabular}{|c|c|c|c|}
\hline & 1 & 2 & 5 \\
\hline $\begin{array}{l}\text { empirical formula } \\
\text { formula wt }\end{array}$ & $\begin{array}{l}\mathrm{C}_{12} \mathrm{H}_{16} \mathrm{ClF}_{12} \mathrm{GaN}_{2} \mathrm{O}_{2} \\
553.44\end{array}$ & $\begin{array}{l}\mathrm{C}_{14} \mathrm{H}_{16} \mathrm{ClF}_{12} \mathrm{GaN}_{2} \mathrm{O}_{2} \\
577.46\end{array}$ & $\begin{array}{l}\mathrm{C}_{8} \mathrm{H}_{14} \mathrm{~F}_{6} \mathrm{GaNO} \\
323.92\end{array}$ \\
\hline temp $(\mathrm{K})$ & $150(1)$ & $150(1)$ & $173(1)$ \\
\hline cryst syst & triclinic & orthorhombic & orthorhombic \\
\hline space group & $\mathrm{P} \overline{1}$ & Pbca & $\mathrm{P} 2_{1} 2_{1} 2_{1}$ \\
\hline$a(\AA)$ & $8.1630(1)$ & $13.2841(2)$ & $8.8758(5)$ \\
\hline $\mathrm{b}(\AA)$ & $9.8163(2)$ & $14.5655(2)$ & $12.3856(7)$ \\
\hline$c(\AA)$ & $13.1765(2)$ & $21.9317(3)$ & $22.4869(13)$ \\
\hline$\alpha$ (deg) & $100.0406(8)$ & & \\
\hline$\beta$ (deg) & $106.0715(8)$ & & \\
\hline$\gamma(\mathrm{deg})$ & $100.8570(9)$ & & \\
\hline$V\left(\AA^{3}\right)$ & $967.29(3)$ & $4243.5(1)$ & $2472.0(2)$ \\
\hline $\mathrm{Z}$ & 2 & 8 & 8 \\
\hline density (calcd) $\left(\mathrm{Mg} / \mathrm{m}^{3}\right)$ & 1.900 & 1.808 & 1.741 \\
\hline abs coeff $\left(\mathrm{mm}^{-1}\right)$ & 1.685 & 1.540 & 2.285 \\
\hline $\mathrm{F}(000)$ & 548 & 2288 & 1296 \\
\hline cryst size $\left(\mathrm{mm}^{3}\right)$ & $0.20 \times 0.20 \times 0.20$ & $0.23 \times 0.12 \times 0.10$ & $0.25 \times 0.2 \times 0.15$ \\
\hline$\theta$ range $(\mathrm{deg})$ & $3.00-27.42$ & $2.27-27.50$ & $1.81-28.72$ \\
\hline index ranges, hkl & $\begin{array}{l}0-10,-12 \text { to }+12 \\
-17 \text { to }+15\end{array}$ & $\begin{array}{l}-15 \text { to }+17,-16 \text { to }+18 \\
-26 \text { to }+28\end{array}$ & $\begin{array}{l}-11 \text { to }+11,-16 \text { to }+16 \\
-30 \text { to }+30\end{array}$ \\
\hline no. of rflns collected & 26958 & 24653 & 29620 \\
\hline no of indep rflns & 4401 (R(int) = 0.0554) & $4873(\mathrm{R}$ (int) $=0.0477)$ & $6375(\mathrm{R}(\mathrm{int})=0.0388)$ \\
\hline no. of data/restraints/params & $4401 / 0 / 272$ & $4873 / 0 / 290$ & $6375 / 0 / 307$ \\
\hline goodness of fit on $\mathrm{F}^{2}$ & 1.034 & 1.027 & 1.045 \\
\hline final $\mathrm{R}$ indices $(\mathrm{I}>2 \sigma(\mathrm{I}))$ & $\mathrm{R} 1=0.0340, w R 2=0.0817$ & $\mathrm{R} 1=0.0382, \mathrm{wR} 2=0.0914$ & $\mathrm{R} 1=0.0266, \mathrm{wR} 2=0.0621$ \\
\hline $\mathrm{R}$ indices (all data) & $\mathrm{R} 1=0.0454, \mathrm{wR} 2=0.0887$ & $\mathrm{R} 1=0.0646, \mathrm{wR} 2=0.1053$ & $\mathrm{R} 1=0.0334, \mathrm{wR} 2=0.0641$ \\
\hline largest diff peak and hole $\left(\mathrm{e} \AA^{-3}\right)$ & 0.562 and -0.505 & 0.368 and -0.395 & 0.604 and -0.241 \\
\hline
\end{tabular}

2 $\left.\mathrm{J} \mathrm{HH}_{\mathrm{H}}=12.0 \mathrm{~Hz},{ }^{3} \mathrm{JH}=4.0 \mathrm{~Hz}\right), 2.88(\mathrm{br}, 1 \mathrm{H}, \mathrm{NH}), 2.79(\mathrm{t}, 1 \mathrm{H}$, $\left.\mathrm{NCH}_{2},{ }^{2} \mathrm{~J} \mathrm{нн}=12.0 \mathrm{~Hz}\right), 2.61\left(\mathrm{~d}, \mathrm{br}, 3 \mathrm{H}, \mathrm{NMe},{ }^{3} \mathrm{Hн}=5.8 \mathrm{~Hz}\right)$, -0.28 (s, 3H, GaMe), -0.34 (s, 3H, GaMe). ${ }^{13} \mathrm{C}$ NMR (100 MHz, $\left.\mathrm{CDCl}_{3}, 298 \mathrm{~K}\right): \delta 124.6\left(\mathrm{q}, \mathrm{CF}_{3},{ }^{1} \mathrm{~J}_{\mathrm{CF}}=287 \mathrm{~Hz}\right), 123.6\left(\mathrm{q}, \mathrm{CF}_{3}\right.$, $\left.{ }^{1} \mathrm{~J}_{\mathrm{CF}}=287 \mathrm{~Hz}\right), 79.2\left(\mathrm{~m}, \mathrm{C}\left(\mathrm{CF}_{3}\right)_{2},{ }^{2} \mathrm{~J}_{\mathrm{CF}}=28.8 \mathrm{~Hz}\right), 51.7(\mathrm{~s}$, $\mathrm{NCH}_{2}$ ), 35.2 (s, NMe), -7.2 (s, GaMe), -8.9 (s, GaMe). ${ }^{19} \mathrm{~F}$ $\operatorname{NMR}\left(470.3 \mathrm{MHz}, \mathrm{CD}_{2} \mathrm{Cl}_{2}, 298 \mathrm{~K}\right): \delta-78.61\left(\mathrm{q}, \mathrm{CF}_{3},{ }^{4} \mathrm{~J}_{\mathrm{FF}}=\right.$ $8.6 \mathrm{~Hz}),-79.27\left(q, \mathrm{CF}_{3}\right.$, $\left.4 \mathrm{FF}=8.6 \mathrm{~Hz}\right)$. Anal. Calcd for $\mathrm{C}_{7} \mathrm{H}_{12} \mathrm{~F}_{6^{-}}$ GaNO: C, 27.13; H, 3.90; N, 4.52. Found: C, 27.18; H, 3.52; N, 4.48 .

Synthesis of 4. Procedures identical with those for $\mathbf{3}$ were followed, using the amino alcohol ligand $\mathrm{HOC}\left(\mathrm{CF}_{3}\right)_{2} \mathrm{CH}_{2} \mathrm{NHBu}^{\mathrm{t}}$ (1.01 $\mathrm{g}, 4 \mathrm{mmol})$ and trimethylgallium $(0.46 \mathrm{~g}, 4 \mathrm{mmol})$ dissolved in $20 \mathrm{~mL}$ of anhydrous diethyl ether. Vacuum sublimation (500 mTorr, $40{ }^{\circ} \mathrm{C}$ ) gave the colorless solid $\left[\mathrm{GaMe}_{2}\left(\mathrm{OC}\left(\mathrm{CF}_{3}\right)_{2} \mathrm{CH}_{2} \mathrm{NHBu}^{\mathrm{t}}\right)\right](4 ; 1.22 \mathrm{~g}, 3.5 \mathrm{mmol})$ in $87 \%$ yield; $\mathrm{mp} 39^{\circ} \mathrm{C}$.

Spectral data of $\mathbf{4}$ are as follows. MS (Cl): $\mathrm{m} / \mathrm{z} 336\left\{\mathrm{M}^{+}-\right.$ $\mathrm{Me}$. ${ }^{1} \mathrm{H}$ NMR $\left(400 \mathrm{MHz}, \mathrm{C}_{6} \mathrm{D}_{6}, 298 \mathrm{~K}\right): \delta 2.92\left(\mathrm{br}, 1 \mathrm{H}, \mathrm{NCH}_{2}\right)$, $2.79\left(\mathrm{br}, 1 \mathrm{H}, \mathrm{NCH}_{2}\right), 2.17(\mathrm{~m}, 1 \mathrm{H}, \mathrm{NH}), 0.52\left(\mathrm{~s}, 9 \mathrm{H}, \mathrm{Bu}^{\mathrm{t}}\right),-0.15$ (s, 6H, GaMe). ${ }^{13} \mathrm{C}$ NMR $\left(100 \mathrm{MHz}, \mathrm{C}_{6} \mathrm{D}_{6}, 298 \mathrm{~K}\right): \delta 125.6$ (q, $\left.\mathrm{CF}_{3},{ }^{1} \mathrm{~J} \mathrm{CF}=286.5 \mathrm{~Hz}\right), 80.4\left(\mathrm{~m}, \mathrm{C}\left(\mathrm{CF}_{3}\right)_{2},{ }^{2} \mathrm{~J} \mathrm{cF}=28.0 \mathrm{~Hz}\right), 54.9$ $\left(\mathrm{s}, \mathrm{NCH}_{2}\right), 44.0$ (s, NHCMe$), 27.9$ (s, Me), -4.2 (s, GaMe). ${ }^{19} \mathrm{~F}$ $\operatorname{NMR}\left(470.3 \mathrm{MHz}, \mathrm{CDCl}_{3}, 298 \mathrm{~K}\right): \delta-78.30\left(\mathrm{q}, \mathrm{CF}_{3},{ }^{4} \mathrm{~J}_{\mathrm{FF}}=\right.$ $8.5 \mathrm{~Hz}),-79.14\left(q, \mathrm{CF}_{3},{ }^{4} \mathrm{JF}=8.5 \mathrm{~Hz}\right)$. Anal. Calcd for $\mathrm{C}_{10} \mathrm{H}_{18} \mathrm{~F}_{6} \mathrm{GaNO}$ : C, 30.25; $\mathrm{H}, 4.57 ; \mathrm{N}, 3.53$. Found: $\mathrm{C}, 30.62$; $\mathrm{H}, 4.49 ; \mathrm{N}, 3.52$.

Synthesis of 5. Procedures identical with those for $\mathbf{3}$ were followed, using the amino al cohol ligand $\mathrm{HOC}\left(\mathrm{CF}_{3}\right)_{2} \mathrm{CH}_{2} \mathrm{NMe}_{2}$ (0.45 g, $2 \mathrm{mmol})$ and trimethylgallium $(0.23 \mathrm{~g}, 2 \mathrm{mmol})$ dissolved in $20 \mathrm{~mL}$ of diethyl ether. Vacuum sublimation (300 mTorr, $\left.50{ }^{\circ} \mathrm{C}\right)$ gave the col orless solid $\left[\mathrm{GaMe}_{2}\left(\mathrm{OC}\left(\mathrm{CF}_{3}\right)_{2} \mathrm{CH}_{2^{-}}\right.\right.$ $\mathrm{NMe}_{2}$ )] (5; $0.46 \mathrm{~g}, 1.4 \mathrm{mmol}$ ) in $70 \%$ yield; $\mathrm{mp} 91{ }^{\circ} \mathrm{C}$. Single crystals suitable for $\mathrm{X}$-ray diffraction study were obtained from sublimation $\left(0.25\right.$ Torr, $\left.100{ }^{\circ} \mathrm{C}\right)$.

Spectral data of 5 are as follows. MS $(\mathrm{Cl}): \mathrm{m} / \mathrm{z} 308\left\{\mathrm{M}^{+}-\right.$ Me\}. ${ }^{1} \mathrm{H}$ NMR (400 MHz, $\left.\mathrm{C}_{6} \mathrm{D}_{6}, 298 \mathrm{~K}\right): \delta 2.39\left(\mathrm{~s}, 2 \mathrm{H}, \mathrm{CH}_{2}\right)$, $1.72\left(\mathrm{~s}, 6 \mathrm{H}, \mathrm{NMe}_{2}\right), 0.04$ (s, 6H, GaMe). ${ }^{13} \mathrm{C} \mathrm{NMR}(100 \mathrm{MHz}$, $\left.\mathrm{C}_{6} \mathrm{D}_{6}, 298 \mathrm{~K}\right): \delta 125.3\left(\mathrm{q}, \mathrm{CF}_{3},{ }^{1} \mathrm{~J}_{\mathrm{CF}}=289.6 \mathrm{~Hz}\right), 81.4(\mathrm{~m}$, $\left.\mathrm{C}\left(\mathrm{CF}_{3}\right)_{2},{ }^{2} \mathrm{~J} \mathrm{CF}=28.3 \mathrm{~Hz}\right), 60.5\left(\mathrm{~s}, \mathrm{NCH}_{2}\right), 48.7\left(\mathrm{~s}, \mathrm{NMe}_{2}\right),-6.6$ (s, GaMe). ${ }^{19} \mathrm{~F} N M R\left(470.3 \mathrm{MHz} \mathrm{CDCl}_{3}, 298 \mathrm{~K}\right): \delta-78.41$ (s, $\mathrm{CF}_{3}$ ). Anal. Calcd for $\mathrm{C}_{8} \mathrm{H}_{14} \mathrm{~F}_{6} \mathrm{GaNO}$ : C, 29.66; $\mathrm{H}, 4.36 ; \mathrm{N}, 4.32$. Found: C, 29.91; H, 4.47; N, 4.37.
X-ray Crystallography. Single-crystal X-ray diffraction data were measured on a Bruker SMART CCD diffractometer using $\lambda($ Mo $K \alpha)$ radiation $\left(\lambda=0.71073 \AA, 2 \theta_{\max } \leq 57.5^{\circ}, \omega\right.$ scan mode) and a graphite monochromator. The data collection was executed using the SMART program. Cell refinement and data reduction were carried out using the SAINT program. The structure was solved using the SHELXTL/PC program and refined using full-matrix least squares. An empirical absorption correction was applied with the SADABS routine (part of the SHELXTL program). The structure was solved by direct methods using the SHELXTL suite of programs. All nonhydrogen atoms were refined anisotropically by full-matrix least squares on $\mathrm{F}^{2}$. Hydrogen atoms were placed in calculated positions and allowed to ride on the parent atoms. Crystallographic refinement parameters of complexes 1, 2, and $\mathbf{5}$ are summarized in Table 1, and selected bond distances and angles for these complexes are listed in Tables 2-4, respectively.

CVD Procedures. The thermal CVD reactions were carried using a horizontal hot-wall reactor described elsewhere. ${ }^{8}$ The deposition chamber consisted of a $30 \mathrm{~cm}$ quartz tube with an internal diameter of $25 \mathrm{~mm}$, placed within a Thermolyne 79300 tube furnace. The Si (100) substrate was cleaned by washing with a dilute HF solution for $2 \mathrm{~h}$, followed by rinsing with deionized water and then acetone, and finally drying at 120 ${ }^{\circ} \mathrm{C}$ for $10 \mathrm{~min}$, while the quartz substrate $\left(\mathrm{SiO}_{2}\right)$ was used as received. The flow rate of the $\mathrm{O}_{2}$ carrier gas was adjusted to 5 sccm, and the deposition time was kept within $3 \mathrm{~h}$. The deposition time was calculated by visually observing consumption of the source compound employed.

\section{Results}

Synthesis and Characterization. The reaction of $\mathrm{GaCl}_{3}$ with 2.2 equiv of a sodium salt of the aminoalkoxide ligand $\mathrm{NaL}=\mathrm{Na}\left[\mathrm{OC}\left(\mathrm{CF}_{3}\right)_{2} \mathrm{CH}_{2} \mathrm{NMe}_{2}\right]$ led to the formation of the air-stable crystall line compound $\mathrm{Ga}$ $\left[\mathrm{OC}\left(\mathrm{CF}_{3}\right)_{2} \mathrm{CH}_{2} \mathrm{NMe}_{2}\right]_{2} \mathrm{Cl}$ (1) in high yield (eq 1).

(8) (a) Tung, Y.-L.; Tseng, W.-C.; Lee, C.-Y.; Chi, Y.; Peng, S.-M.; Lee, G.-H. Organometallics 1999, 18, 864. (b) Chou, T.-Y.; Huang, S.F.; Chi, Y.; Liu, C.-S.; Carty, A. J .; Scoles, L.; Udachin, K. A. Inorg. Chem. 2003, 42, 6041. 


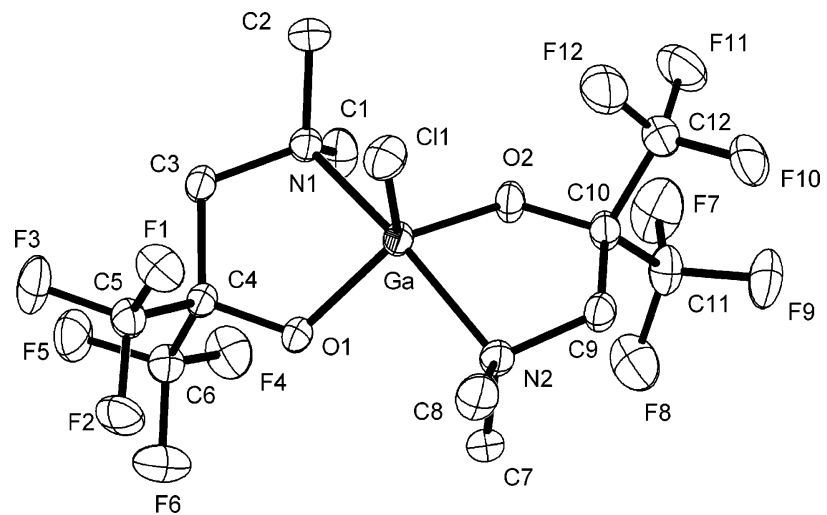

Figure 1. ORTEP drawing of complex $\mathbf{1}$ with thermal ellipsoids shown at the $50 \%$ probability level.

Table 2. Selected Bond Lengths $(\AA)$ and Angles (deg) for Complex 1

\begin{tabular}{lclr}
\hline $\mathrm{Ga}-\mathrm{Cl}(1)$ & $2.1924(6)$ & $\mathrm{Ga}-\mathrm{O}(1)$ & $1.8625(16)$ \\
$\mathrm{Ga}-\mathrm{O}(2)$ & $1.8605(16)$ & $\mathrm{Ga}-\mathrm{N}(1)$ & $2.1179(19)$ \\
$\mathrm{Ga}-\mathrm{N}(2)$ & $2.1301(19)$ & $\mathrm{N}(1)-\mathrm{C}(3)$ & $1.484(3)$ \\
$\mathrm{C}(3)-\mathrm{C}(4)$ & $1.568(3)$ & $\mathrm{O}(1)-\mathrm{C}(4)$ & $1.379(3)$ \\
$\mathrm{N}(2)-\mathrm{C}(9)$ & $1.484(3)$ & $\mathrm{C}(9)-\mathrm{C}(10)$ & $1.568(3)$ \\
$\mathrm{O}(2)-\mathrm{C}(10)$ & $1.373(3)$ & & \\
$\angle \mathrm{N}(1)-\mathrm{Ga}-\mathrm{N}(2)$ & $160.93(8)$ & $\angle \mathrm{N}(1)-\mathrm{Ga}-\mathrm{Cl}(1)$ & $100.27(6)$ \\
$\angle \mathrm{N}(1)-\mathrm{Ga}-\mathrm{O}(1)$ & $83.54(7)$ & $\angle \mathrm{N}(1)-\mathrm{Ga}-\mathrm{O}(2)$ & $89.03(7)$ \\
$\angle \mathrm{N}(2)-\mathrm{Ga}-\mathrm{Cl}(1)$ & $98.79(6)$ & $\angle \mathrm{N}(2)-\mathrm{Ga}-\mathrm{O}(1)$ & $89.11(7)$ \\
$\angle \mathrm{N}(2)-\mathrm{Ga}-\mathrm{O}(2)$ & $82.37(7)$ & $\angle \mathrm{O}(1)-\mathrm{Ga}-\mathrm{Cl}(1)$ & $114.87(6)$ \\
$\angle \mathrm{O}(2)-\mathrm{Ga}-\mathrm{Cl}(1)$ & $114.71(6)$ & $\angle \mathrm{O}(1)-\mathrm{Ga}-\mathrm{O}(2)$ & $130.40(7)$ \\
\multicolumn{5}{c}{$2 \mathrm{NaL}+\mathrm{GaCl}_{3} \rightarrow \mathrm{GaL}_{2} \mathrm{Cl}+2 \mathrm{NaCl}$} \\
\multicolumn{4}{c}{$\mathbf{1}$} \\
$\mathrm{L}=\mathrm{OC}\left(\mathrm{CF}_{3}\right)_{2} \mathrm{CH}_{2} \mathrm{NMe}_{2}$
\end{tabular}

Electron impact mass analysis showed a parent ion at $\mathrm{m} / \mathrm{z} 517$ due to the Ga-containing fragment ion $\mathrm{Ga}[\mathrm{OC}$ $\left.\left(\mathrm{CF}_{3}\right)_{2} \mathrm{CH}_{2} \mathrm{NMe}_{2}\right]_{2}{ }^{+}$. This complex was further characterized by ${ }^{1} \mathrm{H}$ and ${ }^{13} \mathrm{C}$ NMR spectroscopy, the ${ }^{1} \mathrm{H}$ spectra exhibiting an $A B$ pattern for the methylene functional group at $\delta 2.50$ and 2.18 with the coupling constant 2] $\mathrm{HH}=14.6 \mathrm{~Hz}$, as well as two distinctive methyl signals at $\delta 2.05$ and 2.04 derived from the $\mathrm{NMe}_{2}$ functional groups. In addition, the ${ }^{19} \mathrm{~F}$ NMR resonance signals observed at $\delta-76.83$ and -78.20 with the coupling constant ${ }^{4} \mathrm{JFF}=11.9 \mathrm{~Hz}$ are consistent with those of typical nonequivalent $\mathrm{CF}_{3}$ substituents, reflecting the lack of apparent mirror symmetry within the alkoxide ligands.

The crystal structure of $\mathbf{1}$ has been determined to provide details of the molecular stereochemistry, and selected bond distances and angles are summarized in Table 2. As shown in Figure 1, the gallium center is coordinated to one chloride and two chelating fluoroal koxide ligands. The unique chloride ligand resides at an equatorial position with a $\mathrm{Ga}-\mathrm{Cl}$ distance of 2.1924(6) $\AA$, which is similar to that of other chlorine-containing compounds, such as $[(\mathrm{Me})(\mathrm{Cl}) \mathrm{GaNH}(\mathrm{TMS})]_{2}$ (2.212(3) $\AA),{ }_{1}^{9}\left[\mathrm{Cl}_{2} \mathrm{GaNH}(\mathrm{TMS})\right]_{2}$, and $\left[\mathrm{Cl}_{2} \mathrm{GaNMe} \text { (TMS) }\right]_{2}(2.14-$ $2.15 \AA) .{ }^{10}$ The fluoroalkoxide ligands are coordinated to the gallium center through both of their oxygen and nitrogen atoms. Thus, the gallium center has a trigonal-

(9) Nutt, W. R.; Stimson, R. E.; Leopold, M. F.; Rubin, B. H. Inorg. Chem. 1982, 21, 1909 .

(10) Nutt, W. R.; Anderson, J . A.; Odom, J . D.; Williamson, M. M.; Rubin, B. H. Inorg. Chem. 1985, 24, 159. bipyramidal geometry with the $N(1)$ and $N(2)$ atoms occupying the axial positions with $\angle \mathrm{N}(1)-\mathrm{Ga}-\mathrm{N}(2)=$ $160.93(8)^{\circ}$ and the $\mathrm{O}(1)$ and $\mathrm{O}(2)$ atoms occupying the equatorial positions with $\angle \mathrm{O}(1)-\mathrm{Ga}-\mathrm{O}(2)=130.40(7)^{\circ}$. A similar distorted-trigonal-bipyramidal geometry has been noted in the related five-coordinate complexes $\mathrm{GaL}_{2} \mathrm{Cl}$ and $\mathrm{GaL}_{3}$, where $\mathrm{L}=-\mathrm{C}_{6} \mathrm{H}_{4}-\mathrm{O}-\mathrm{CH}_{2} \mathrm{NMe}_{2} \cdot{ }^{11}$

Moreover, the $\mathrm{Ga}-\mathrm{O}$ bond distances within the molecule $(\mathrm{Ga}-\mathrm{O}(1)=1.8625(16)$ and $\mathrm{Ga}-\mathrm{O}(2)=1.8605$ (16) $\AA$ ) are nearly equal. These data compare well with those of the pyridine-stabilized, four-coordinated alkoxide complexes $\mathrm{Ga}\left[\mathrm{OCH}\left(\mathrm{CF}_{3}\right)_{2}\right]_{3}\left(4-\mathrm{Me}_{2} \mathrm{Npy}\right)$ and $\mathrm{Ga}$ $\left[\mathrm{OCMe}_{2}\left(\mathrm{CF}_{3}\right)\right]_{3}\left(4-\mathrm{Me}_{2} \mathrm{~N} \mathrm{py}\right)(\sim 1.801(5) \AA),{ }^{3}$ as well as the alkyl complexes $\left(\mathrm{Bu}^{\mathrm{t}}\right)_{2} \mathrm{Ga}\left(\mathrm{OBu}^{\mathrm{t}}\right)\left(\mathrm{O}=\mathrm{AsPh}_{3}\right) \quad(1.860(6)$ $\AA), 12 \mathrm{Me}_{2} \mathrm{Ga}\left[\mathrm{O}\left(\mathrm{C}_{5} \mathrm{H}_{3} \mathrm{~N}\right) \mathrm{CH}_{2} \mathrm{NMe}_{2}\right]$ (1.892(3) $\AA$ ), ${ }^{13}$ and $\left(\mathrm{Bu}^{\mathrm{t}}\right)_{2} \mathrm{GaOR}$, where $\mathrm{R}=2,6-\mathrm{Bu}_{2}^{\mathrm{t}}-4-\mathrm{MeC}_{6} \mathrm{H}_{2}(1.821$ (3) $\AA$ ) and $\mathrm{R}=\mathrm{CPh}_{3}(1.831(4) \AA) \cdot{ }^{14}$ The observed donoracceptor $\mathrm{Ga}-\mathrm{N}$ distances $(\mathrm{Ga}-\mathrm{N}(1)=2.1179(19) \AA$ and $\mathrm{Ga}-\mathrm{N}(2)=2.1301(19) \AA$ ) are substantially longer than those of formally covalent $\mathrm{Ga}-\mathrm{N}$ bonds (1.82-1.94 $\AA$ ) of the other amide compounds, as summarized by Brothers and Power. ${ }^{15}$ The longer $\mathrm{Ga}-\mathrm{N}$ bond distances are in good agreement with axial coordination positions and the formation of relatively weak neutral donormetal bonding interactions.

The reaction between $\mathrm{GaCl}_{3}$ and the analogous iminoalkoxide ligand $\mathrm{NaL}=\mathrm{Na}\left[\mathrm{OC}\left(\mathrm{CF}_{3}\right)_{2} \mathrm{CH}_{2} \mathrm{C}(\mathrm{Me})=\right.$ $\mathrm{NMe}$ ] was also conducted, leading to the formation of the similar product $\mathrm{Ga}\left[\mathrm{OC}\left(\mathrm{CF}_{3}\right)_{2} \mathrm{CH}_{2} \mathrm{C}(\mathrm{Me})=\mathrm{NMe}\right]_{2} \mathrm{Cl}$ (2). Although this compound is clearly less stable upon

$$
\begin{gathered}
2 \mathrm{NaL}+\mathrm{GaCl}_{3} \rightarrow \underset{\mathbf{2}}{\mathrm{GaL}_{2} \mathrm{Cl}}+\underset{2 \mathrm{NaCl}}{\mathrm{L}}=\mathrm{OC}\left(\mathrm{CF}_{3}\right)_{2} \mathrm{CH}_{2} \mathrm{C}(\mathrm{Me})=\mathrm{NMe}
\end{gathered}
$$

exposure to air and moisture, it can be sublimed under reduced pressure (500 mTorr and at $75{ }^{\circ} \mathrm{C}$ ) without notable decomposition. The EI mass spectrum showed a peak at $\mathrm{m} / \mathrm{z} 576$, indicating the presence of the molecular ion $\mathrm{M}^{+}$. The ${ }^{1} \mathrm{H}$ NMR spectrum showed only one imino methyl group at $\delta 2.91$, suggesting that the iminoal koxide ligands are symmetrically related. The single-crystal $X$-ray diffraction study was then examined to reveal the stereochemistry. As indicated in Figure 2, the core structure of $\mathbf{2}$ is basically akin to that of the previously determined structure of $\mathbf{1}$, giving the expected trigonal-bipyramidal coordination geometry. (Table 3 gives selected bond distances and angles for $\mathbf{2}$.) However, the $\mathrm{Ga}-\mathrm{Cl}$ and the $\mathrm{Ga}-\mathrm{O}$ distances are both approximately $0.03 \AA$ longer and are accompanied by a simultaneous $0.03 \AA$ reduction of the respective $\mathrm{Ga}-\mathrm{N}$ distances, due to the formation of the stronger donoracceptor bonding expected for the imino $\mathrm{N}$ atom. Moreover, since the skel eton of the iminoalkoxide chelate in $\mathbf{2}$ would be more flexible than the aminoalkoxide che

(11) Coggin, D. K.; Fanwick, P. E.; Green, M. A. J . Chem. Soc., Chem. Commun. 1993, 1127

(12) Power, M. B.; Ziller, J . W.; Barron, A. R. Organometallics 1993, 12, 4908

(13) Onyiriuka, E. C.; Rettig, S. J .; Storr, A.; Trotter, J . Can. J Chem. 1987, 65, 782.

(14) (a) Petrie, M. A.; Olmstead, M. M.; Power, P. P. J . Am. Chem Soc. 1991, 113, 8704. (b) Cleaver, W. M.; Barron, A. R. Organometallics 1993, 12, 1001.

(15) Brothers, P. J .; Power, P. P. Adv. Organomet. Chem. 1996, 39, 


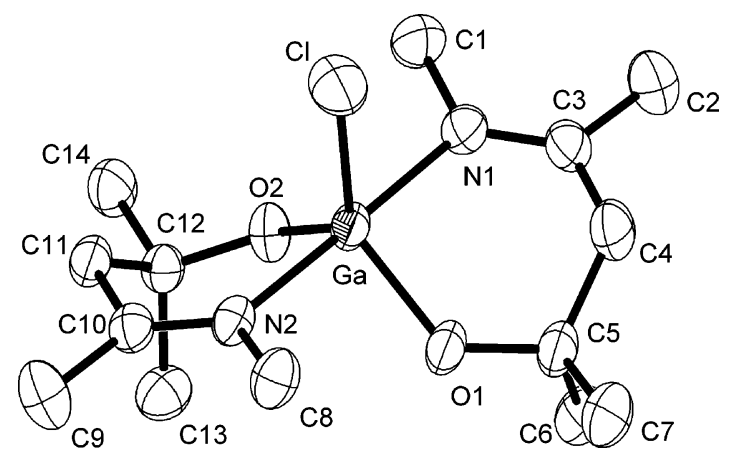

Figure 2. ORTEP drawing of complex $\mathbf{2}$ with thermal ellipsoids shown at the $50 \%$ probability leve. Fluorine atoms of the $\mathrm{CF}_{3}$ substituents were removed for clarity.

Table 3. Selected Bond Lengths $(\AA)$ and Angles (deg) for Complex 2

\begin{tabular}{llll}
\hline $\mathrm{Ga}-\mathrm{Cl}$ & $2.2134(8)$ & $\mathrm{Ga}-\mathrm{O}(1)$ & $1.8432(18)$ \\
$\mathrm{Ga}-\mathrm{O}(2)$ & $1.8364(19)$ & $\mathrm{Ga}-\mathrm{N}(1)$ & $2.087(2)$ \\
$\mathrm{Ga}-\mathrm{N}(2)$ & $2.092(2)$ & $\mathrm{N}(1)-\mathrm{C}(3)$ & $1.278(4)$ \\
$\mathrm{C}(3)-\mathrm{C}(4)$ & $1.499(4)$ & $\mathrm{C}(4)-\mathrm{C}(5)$ & $1.537(4)$ \\
$\mathrm{O}(1)-\mathrm{C}(5)$ & $1.369(3)$ & $\mathrm{N}(2)-\mathrm{C}(10)$ & $1.284(3)$ \\
$\mathrm{C}(10)-\mathrm{C}(11)$ & $1.512(4)$ & $\mathrm{C}(11)-\mathrm{C}(12)$ & $1.537(4)$ \\
$\mathrm{O}(2)-\mathrm{C}(12)$ & $1.373(3)$ & & \\
$\angle \mathrm{N}(1)-\mathrm{Ga}-\mathrm{N}(2)$ & $178.87(9)$ & $\angle \mathrm{N}(1)-\mathrm{Ga}-\mathrm{Cl}$ & $90.13(7)$ \\
$\angle \mathrm{N}(1)-\mathrm{Ga}-\mathrm{O}(1)$ & $93.30(9)$ & $\angle \mathrm{N}(1)-\mathrm{Ga}-\mathrm{O}(2)$ & $86.33(9)$ \\
$\angle \mathrm{N}(2)-\mathrm{Ga}-\mathrm{Cl}$ & $89.68(6)$ & $\angle \mathrm{N}(2)-\mathrm{Ga}-\mathrm{O}(1)$ & $87.75(9)$ \\
$\angle \mathrm{N}(2)-\mathrm{Ga}-\mathrm{O}(2)$ & $92.86(9)$ & $\angle \mathrm{O}(1)-\mathrm{Ga}-\mathrm{Cl}$ & $121.34(7)$ \\
$\angle \mathrm{O}(2)-\mathrm{Ga}-\mathrm{Cl}$ & $124.20(7)$ & $\angle \mathrm{O}(1)-\mathrm{Ga}-\mathrm{O}(2)$ & $114.46(9)$
\end{tabular}

lates in $\mathbf{1}$ due to the formation of a puckered fivemembered chelate structure, the relief of the internal ring strain results in a linear axial $\mathrm{N}(1)-\mathrm{Ga}-\mathrm{N}(2)$ arrangement with angle $178.87(9)^{\circ}$ and simultaneous reduction of the $\mathrm{O}(1)-\mathrm{Ga}-\mathrm{O}(2)$ angle to $\sim 114^{\circ}$.

In contrast to the aforementioned reactions of aminoalkoxide and $\mathrm{GaCl}_{3}$, the corresponding reactions of amino alcohol ligands and trimethylgallium, GaMes, proceeded with the elimination of only one methyl substituent and afforded complexes of formulas $\mathrm{GaMe}_{2} \mathrm{~L}$ (eq 3).

$$
\begin{aligned}
& \mathrm{LH}+\mathrm{GaMe}_{3} \rightarrow \mathrm{GaMe}_{2} \mathrm{~L}+\mathrm{CH}_{4} \\
& \text { 3-5 } \\
& \mathrm{L}=\mathrm{OC}\left(\mathrm{CF}_{3}\right)_{2} \mathrm{CH}_{2} \mathrm{NHMe} \mathrm{(3),} \\
& \mathrm{OC}\left(\mathrm{CF}_{3}\right)_{2} \mathrm{CH}_{2} \mathrm{NHBu}^{\mathrm{t}} \text { (4), OC( }\left(\mathrm{CF}_{3}\right)_{2} \mathrm{CH}_{2} \mathrm{NMe}_{2} \text { (5) }
\end{aligned}
$$

These reactions occurred rapidly in diethyl ether solution at $0{ }^{\circ} \mathrm{C}$. However, if an excess of amino alcohol ligands $\mathrm{LH}$, higher temperatures, and longer reaction times were employed, the formation of highly airsensitive byproducts occurred, although the monosubstituted Ga complexes $\mathbf{3} \mathbf{- 5}$ still remained as the major products. It is possible that these byproducts may be of the type $\mathrm{GaL}_{2} \mathrm{Me}$, in which two methyl substituents have been replaced by the incoming amino alcohol ligands. However, no attempt was made to identify these $\mathrm{GaL}_{2} \mathrm{M}$ e products, due to their low yields and poor stability.

Compl exes 3-5 are colorless solids which are slowly decomposed by moisture or atmospheric oxygen over a period of $24 \mathrm{~h}$. The NHMe-substituted complex $\mathbf{3}$ is particularly sensitive and is converted from well-defined crystals into a gummy material within approximately $3 \mathrm{~h}$ upon exposure to humid air. Thus, purification of

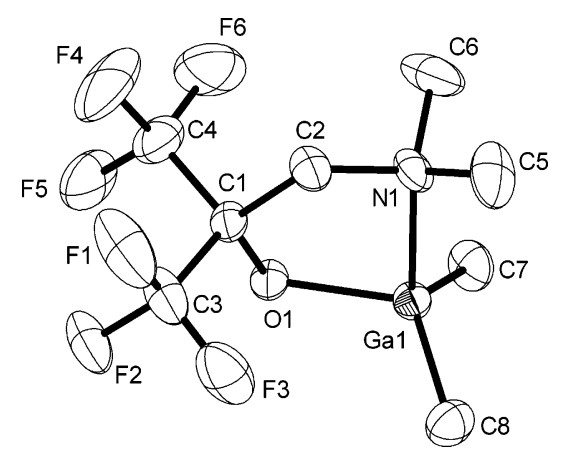

Figure 3. ORTEP drawing of complex $\mathbf{5}$ with thermal ellipsoids shown at the $50 \%$ probability level.

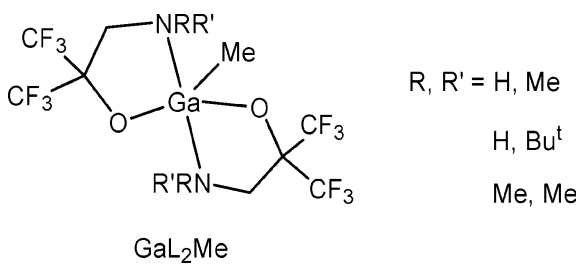

these compounds is best carried out by vacuum sublimation. The complexes are highly soluble in organic solvents such as diethyl ether and hydrocarbons but undergo slow decomposition in chlorinated solvents such as $\mathrm{CHCl}_{3}$ to afford insoluble precipitates. The most stable derivative appears to be the tert-butyl complex 4, which is virtually unaffected by $\mathrm{CHCl}_{3}$ under an inert $\mathrm{N}_{2}$ atmosphere, while $\mathbf{3}$ formed an insoluble precipitate within approximately 2 days.

The X-ray structural analysis of $\mathbf{5}$ was carried out to establish details of their molecular structures (Figure 3; selected bond distances and angles are given in Table 4). The central Ga atom is surrounded by two methyl groups as well as one oxygen and one nitrogen atom derived from the aminoalkoxide chelate. Moreover, the $\mathrm{Ga}$ atom has a distorted-tetrahedral environment ${ }^{16}$ with all bond angles situated in the range 107.6-125.0 . Apparently, coordinative unsaturation of the $\mathrm{Ga}$ atom is satisfied by a dative interaction with the nitrogen atom, and there is no indication of the formation of additional gallium-donor interactions. Notable structural parameters include the $\mathrm{Ga}(1)-\mathrm{N}(1)$ distance of $2.082(2) \AA$, which is comparable to that observed in the related complexes $\mathbf{1}$ and $\mathbf{2}(2.087-2.130 \AA)$ as well as in an organogallium complex which exhibits intramolecular $\mathrm{N} \rightarrow \mathrm{Ga}$ dative bonding $(2.095(2) \AA) .{ }^{17}$ However, this $\mathrm{Ga}(1)-\mathrm{N}(1)$ bond length is significantly shorter than the el ongated $\mathrm{Ga}-\mathrm{N}$ distance $(2.525(2) \AA$ ) observed in the nonfluorinated aminoalkoxide dimer complex $\left[\mathrm{GaMe}_{2} \mathrm{~L}\right]_{2}\left(6 ; \mathrm{L}=\mathrm{CHMeCH}_{2} \mathrm{NMe}_{2}\right) .{ }^{18}$ The latter contains a four-membered $\mathrm{Ga}_{2} \mathrm{O}_{2}$ central skel eton with the $\mathrm{Ga}-\mathrm{N}$ vector being located axially trans to the bridging alkoxide. Moreover, the nonbonding Ga... O distance to the alkoxide oxygen atom of the neighboring molecule in $\mathbf{5}$ is $5.88 \AA$, ruling out any additional donor-acceptor bonding at the vacant coordination position trans to the

(16) Schumann, H.; Hartmann, U.; Wassermann, W.; Dietrich, A.; Goerlitz, F. H.; Ludwig, P.; Martin, H. Chem. Ber. 1990, 123, 2093.

(17) Schumann, H.; Hartmann, U.; Dietrich, A.; Pickardt, J . Angew. Chem., Int. Ed. Engl. 1988, 27, 1077.

(18) (a) Thiele, K.-H.; Hecht, E.; Gelbrich, T.; Duemichen, U. J . Organomet. Chem. 1997, 540, 89. (b) Schumann, H.; Wernik, S.; Wassermann, B. C.; Girgsdies, F. J . Organomet. Chem. 2001, 621, 317. 
Table 4. Selected Bond Lengths $(\AA \AA)$ and Angles (deg) for Complex 5

\begin{tabular}{lcll}
\hline $\mathrm{Ga}(1)-\mathrm{O}(1)$ & $1.890(2)$ & $\mathrm{Ga}(1)-\mathrm{N}(1)$ & $2.082(2)$ \\
$\mathrm{Ga}(1)-\mathrm{C}(7)$ & $1.952(3)$ & $\mathrm{Ga}(1)-\mathrm{C}(8)$ & $1.966(3)$ \\
$\mathrm{N}(1)-\mathrm{C}(5)$ & $1.489(4)$ & $\mathrm{N}(1)-\mathrm{C}(2)$ & $1.489(3)$ \\
$\mathrm{N}(1)-\mathrm{C}(6)$ & $1.485(4)$ & $\mathrm{O}(1)-\mathrm{C}(1)$ & $1.368(3)$ \\
$\mathrm{C}(1)-\mathrm{C}(2)$ & $1.558(3)$ & & \\
& & & \\
$\angle \mathrm{N}(1)-\mathrm{Ga}(1)-\mathrm{O}(1)$ & $85.01(8)$ & $\angle \mathrm{Ga}(1)-\mathrm{O}(1)-\mathrm{C}(1)$ & $116.05(14)$ \\
$\angle \mathrm{O}(1)-\mathrm{C}(1)-\mathrm{C}(2)$ & $113.74(19)$ & $\angle \mathrm{N}(1)-\mathrm{C}(2)-\mathrm{C}(1)$ & $111.9(2)$ \\
$\angle \mathrm{Ga}(1)-\mathrm{N}(1)-\mathrm{C}(2)$ & $104.76(15)$ & $\angle \mathrm{C}(7)-\mathrm{Ga}(1)-\mathrm{C}(8)$ & $124.99(13)$ \\
$\angle \mathrm{N}(1)-\mathrm{Ga}(1)-\mathrm{C}(7)$ & $110.24(11)$ & $\angle \mathrm{N}(1)-\mathrm{Ga}(1)-\mathrm{C}(8)$ & $107.60(11)$ \\
$\angle \mathrm{O}(1)-\mathrm{Ga}(1)-\mathrm{C}(7)$ & $109.60(11)$ & $\angle \mathrm{O}(1)-\mathrm{Ga}(1)-\mathrm{C}(8)$ & $112.11(11)$
\end{tabular}
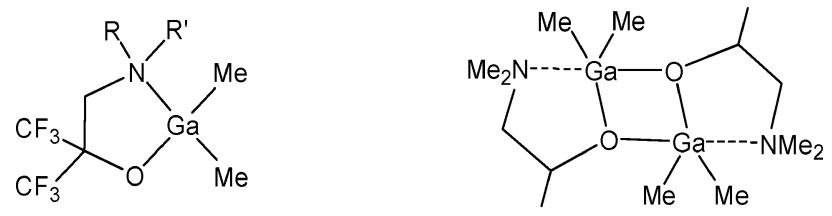
(3) $\mathrm{R}=\mathrm{H}, \mathrm{R}^{\prime}=\mathrm{Me}$
(4) $R=H, R^{\prime}=B u^{t}$
(5) $R=R^{\prime}=M e$

(6)

$\mathrm{NMe}_{2}$ donor group. It is possible that both steric repulsion and the presence of electron-withdrawing $\mathrm{CF}_{3}$ substituents of the aminoalkoxide ligand reduce the bridging capability of the oxygen atom, which then inhibits formation of the dimer structure.

The solution fluxionality of complexes 3-5 was investigated by variable-temperature ${ }^{1} \mathrm{H}$ NMR spectroscopy. First of all, the ${ }^{1} \mathrm{H}$ NMR spectra of $\mathbf{5}$ showed no temperature-dependent behavior, due to the possession of a mirror plane that bisects the molecule. However, for the NHMe-substituted complex 3, two sharp GaMe resonances appeared at $\delta-0.28$ and -0.34 with equal intensity in $\mathrm{CDCl}_{3}$ solution at $298 \mathrm{~K}$. When the temperature was increased to $315 \mathrm{~K}$, these signals coalesced and merged to form one broad signal and then to form a very sharp signal at $\delta-0.30$ on warming to $323 \mathrm{~K}$. This temperature-dependent exchange behavior is consistent with cleavage of the $\mathrm{N} \rightarrow \mathrm{Ga}$ dative bond, followed by rapid free rotation about the $\mathrm{C}-\mathrm{N}$ vector connected to the asymmetric NHMe fragment and regeneration of the original $\mathrm{N} \rightarrow \mathrm{Ga}$ linkage. As this dynamic motion would cause a rapid interchange of the hydrogen atoms and the methyl group on the nitrogen atom, formation of an averaged chemical environment for the adjacent $\mathrm{GaMe}_{2}$ fragment would be expected at the higher temperatures. From the coalescence temperature $\left(T_{c}=315 \mathrm{~K}\right)$ and the chemical shift difference $(\Delta v=28.5 \mathrm{~Hz})$, the estimated free energy of activation $\Delta \mathrm{G}^{\ddagger}=67 \mathrm{~kJ} / \mathrm{mol}$ was obtained for this dynamic motion of 3. A similar value of $\Delta \mathrm{G}^{\ddagger}=65 \mathrm{~kJ} / \mathrm{mol}$ (calculated from $\mathrm{T}_{\mathrm{c}}=315 \mathrm{~K}$ and $\Delta v=51 \mathrm{~Hz}$ ) was also obtained from an experiment conducted in toluene- $d_{8}$, showing no significant solvent effect.

The fluxional behavior of the NHBut-substituted complex $\mathbf{4}$ was then investigated for a direct comparison. As shown in Figure 4, the ${ }^{1} \mathrm{H}$ NMR spectra recorded in $\mathrm{CDCl}_{3}$ solution exhibit two $\mathrm{Ga}-\mathrm{Me}$ resonances at 298 $\mathrm{K}$, and when the temperature is raised to $338 \mathrm{~K}$, these signals then merge to give one resonance at $\delta-0.24$. The estimated free energy $\Delta \mathrm{G}^{\ddagger}=72 \mathrm{~kJ} / \mathrm{mol}$, calculated using $\mathrm{T}_{\mathrm{C}}=330 \mathrm{~K}$ and $\Delta v=12 \mathrm{~Hz}$, is also quite similar to that of $\mathbf{3}$, suggesting that replacement of a methyl group by the more bulky $\mathrm{Bu}^{\mathrm{t}}$ substituent has little influence on the activation barrier in the $\mathrm{CDCl}_{3}$ solution. In marked contrast to this observation, the $\mathrm{GaMe}_{2}$ fragment appears as only one signal at $\delta 0.02$ at $298 \mathrm{~K}$ when the NMR solvent is changed to toluene- $d_{8}$, and the low-temperature limiting spectrum with two equally intense $\mathrm{Ga}-\mathrm{Me}$ signals at $\delta 0.14$ and 0.16 is observed only at the very low temperature of $213 \mathrm{~K}$. Thus, the calculated exchange barrier in the toluene solution $\left(\Delta \mathrm{G}^{\ddagger}=50 \mathrm{~kJ} / \mathrm{mol}, \mathrm{T}_{\mathrm{C}}=228 \mathrm{~K}\right.$ and $\left.\Delta v=9.5 \mathrm{~Hz}\right)$ becomes substantially lower than that recorded in $\mathrm{CDCl}_{3}$ solution. We speculate that this reduction in energy barrier may be due to solvent interaction with the Ga metal complex 4, in which the weak $\mathrm{N} \rightarrow \mathrm{Ga}$ dative bond formed by the bulky $\mathrm{NHBu}^{\mathrm{t}}$ group may induce formation of a transient bonding interaction with the donor solvent:

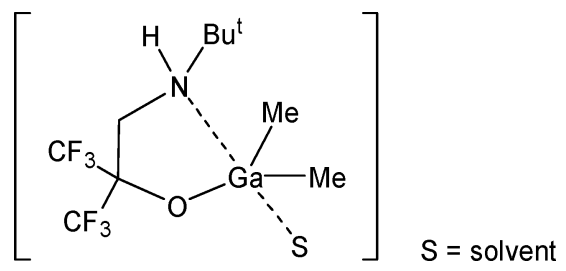

In turn, solvent coordination might induce a further weakening of the $\mathrm{N} \rightarrow \mathrm{Ga}$ interaction, which would then lower the observed energy barrier of isomerization, since free rotation about the $\mathrm{C}-\mathrm{N}$ bond would become much easier. In support of this hypothesis, solvent-induced intramolecular isomerization was also detected using THF- $\mathrm{d}_{8}$ as the solvent. In this experiment, a nearly identical $\Delta \mathrm{G}^{\ddagger}=50 \mathrm{~kJ} / \mathrm{mol}$ was obtained, but the temperature dependence of the chemical shifts was less notable than those recorded in toluene- $d_{8}$ solution. In contrast, the related NHMe complex $\mathbf{3}$ showed no rate enhancement, presumably because the smaller $\mathrm{NHMe}$ fragment would provide less destabilization to the $\mathrm{N} \rightarrow \mathrm{Ga}$ dative interaction and discourage the solvent coordination during the VT ${ }^{1} \mathrm{H}$ NMR measurement. For a further comparison, similar fluxional behavior has been documented in the dimeric amido complex [ $\mathrm{Me}_{2}-$ $\left.\mathrm{Ga}\left(u-\mathrm{NHBu}^{\mathrm{t}}\right)\right]_{2} \cdot{ }^{19}$ In this system, intramolecular cistrans isomerization involving the cleavage and regeneration of the $\mathrm{N}-\mathrm{Ga}$ bond was determined to have the higher activation parameters $\Delta \mathrm{H} \approx 120 \mathrm{~kJ} / \mathrm{mol}$ and $\Delta \mathrm{S}$ $\approx 40 \mathrm{~J} /(\mathrm{mol} \mathrm{K})$ and, most importantly, the isomerization was markedly accelerated in the presence of pyridine.

Thermal Analysis. The volatility and thermal stability of complexes $\mathbf{1}$ and 3-5 were investigated by thermogravimetric analysis (TGA) under an atmospheric pressure of $\mathrm{N}_{2}$ (Figure S1 in the Supporting Information). TGA data for the iminoalkoxide complex 2 were not recorded due to its poor stability, which makes sample loading in air a very difficult manipulation. Generally speaking, the TGA pattern of $\mathbf{1}$ is characterized by a single-stage weight loss started at $130{ }^{\circ} \mathrm{C}$, while evaporation of sample is al most complete at $180{ }^{\circ} \mathrm{C}$, giving a small amount of brownish residue ( 0.9 wt \%). In contrast, the $\mathrm{GaMe}_{2}$ complexes 3-5 showed much lower onset temperatures at $\sim 70{ }^{\circ} \mathrm{C}$ due to the lower molecular weight and, when the temperature was increased to $150{ }^{\circ} \mathrm{C}$, the residual weight then

(19) (a) Park, J . T.; Kim, Y.; Kim, J .; Kim, K.; Kim, Y. Organome tallics 1992, 11, 3320. (b) Kim, Y.; Kim, J . H.; Park, J . E.; Song, H.; Park, J. T. J . Organomet. Chem. 1997, 545-546, 99. 

(a) $\mathrm{CDCl}_{3}$
(b) $d_{8}$-toluene
(c) $\mathrm{d}_{8}$-THF

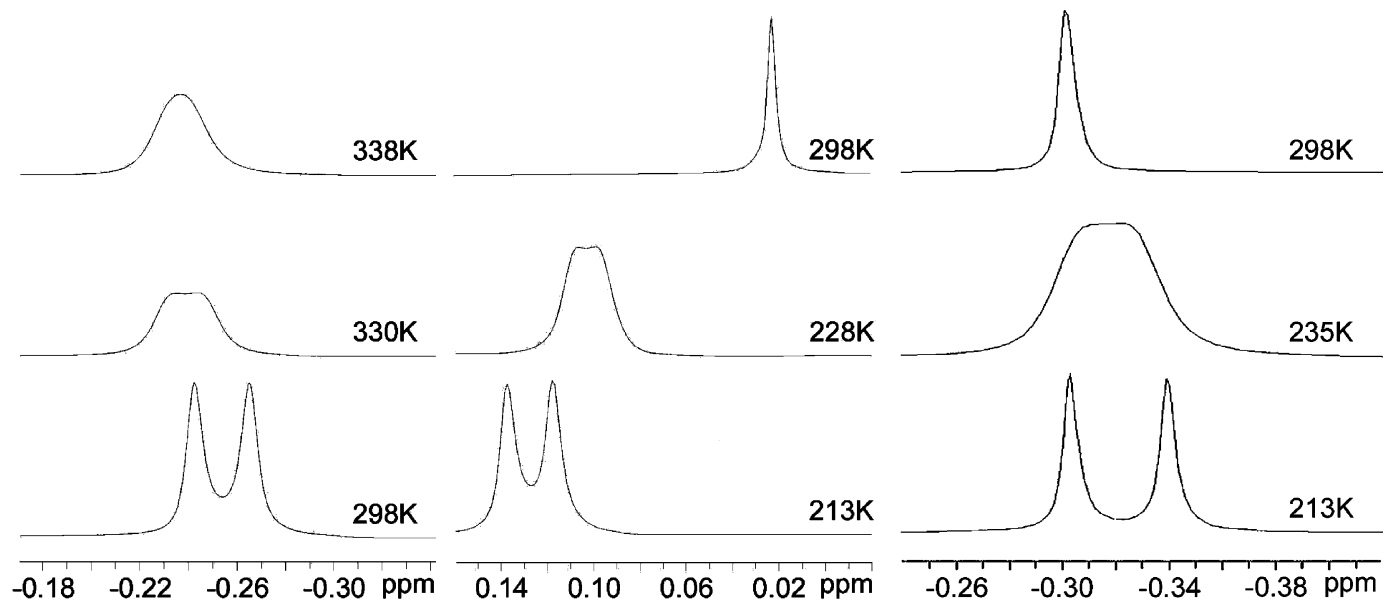

Figure 4. Variabletemperature ${ }^{1} \mathrm{H}$ NMR spectra of $\mathbf{4}$ with an emphasis in the region of the GaMe signal. The spectra were recorded in (a) $\mathrm{CDCl}_{3}$, (b) toluene- $\mathrm{d}_{8}$, and (c) THF-d solution.

\section{Table 5. Parameters of the CVD Experiments and the Analytical Data of $\mathrm{Ga}_{2} \mathrm{O}_{3}$ Thin Films}

\begin{tabular}{cccccccc}
\hline $\begin{array}{c}\text { film no. } \\
\text { (source compd) }\end{array}$ & $\begin{array}{c}\mathrm{T}_{\mathrm{s}} \\
\left({ }^{\circ} \mathrm{C}\right)\end{array}$ & $\begin{array}{c}\mathrm{T}_{d} \\
\left({ }^{\circ} \mathrm{C}\right)\end{array}$ & $\begin{array}{c}\mathrm{P}_{\mathrm{s}} \\
(\mathrm{T} o r r)\end{array}$ & $\begin{array}{c}\text { thick- } \\
\text { ness }(\AA)\end{array}$ & $\mathrm{O} / \mathrm{Ga}^{\mathrm{b}}$ & $\mathrm{O} / \mathrm{Ga}^{\mathrm{c}}$ & $\mathrm{C} / \mathrm{Ga}^{\mathrm{b}}$ \\
\hline $1(\mathbf{1})$ & 65 & 500 & 3 & 910 & 1.18 & 1.50 & 0.03 \\
$2(\mathbf{1})$ & 65 & 600 & 3 & 960 & 1.22 & 1.55 & 0.05 \\
$3(\mathbf{4})$ & 45 & 500 & 5 & 770 & 1.13 & 1.50 & 0.04 \\
$4(\mathbf{4})$ & 45 & 600 & 5 & 1200 & 1.30 & 1.65 & 0.05
\end{tabular}

a Abbreviations: $T_{s}$, source temperature; $T_{d}$, deposition temperature; $P_{s}$, system pressure. The gas DR (deposition rate) was $5 \mathrm{sccm}$, and the gas used was $\mathrm{O}_{2}$ in all cases. ${ }^{b}$ Data measured from XPS analysis. ' Data measured from RBS analysis.

dropped to their minima, 2.9-4.3 wt \%. An identical TGA pattern was observed for the dimethyl complexes 3-5, implying that the alkyl group of the aminoalkoxide chel ates has little influence on their relative volatilities.

CVD Experiments. Gallium oxide, $\mathrm{Ga}_{2} \mathrm{O}_{3}$, deposition was achieved using the two representative source complexes $\mathbf{1}$ and $\mathbf{4}$ in a standard horizontal hot wall reactor, with high-purity $\mathrm{O}_{2}$ as the carrier gas. In general, the sample reservoir was kept at a temperature setting between 65 and $45^{\circ} \mathrm{C}$, depending on the relative volatility revealed by TG analysis, while the deposition temperature was maintained in the range $500-600{ }^{\circ} \mathrm{C}$ with system pressures being 3-5 Torr. These experimental parameters are summarized in Table 5 .

For the source complex $\mathbf{1}$ the as-deposited thin films were light yellow and transparent at $500{ }^{\circ} \mathrm{C}$. They turned slightly darker upon increasing the deposition temperature. All of the films adhered very well to the substrate surface (both Si wafer and quartz glass). The XRD pattern of the as-deposited thin films was featureless, illustrating the amorphous nature of the films. U pon annealing at $900{ }^{\circ} \mathrm{C}$ for $4 \mathrm{~h}$, two weak signals at $2 \theta=30.1$ and $31.7^{\circ}$ became observable, corresponding to the $(400)$ and $(002)$ reflections of the $\mathrm{Ga}_{2} \mathrm{O}_{3}$ phase. ${ }^{20}$ As indicated in Figure 5, the SEM images of the thin film deposited at $\sim 500{ }^{\circ} \mathrm{C}$ possessed a flat surface morphology with a thickness of $\sim 910 \AA$. When the deposition temperatures were raised to $600{ }^{\circ} \mathrm{C}$, the surface turned much rougher and large crystallites with

(20) (a) Wu, P.; Gao, Y.-M.; Kershaw, R.; Wold, A. Mater. Res. Bull. 1990, 25, 357. (b) J oint Commission on Powder Diffraction Spectroscopy (J CPDS), International Center for Diffraction Data, Card No. 411103, Swarthmore, PA, 2000. well-defined grain boundaries were observed, which is in good agreement with the typical trend of increased crystallite size upon raising the temperature.

The chemical binding state and thin film composition were investigated by X-ray photoel ectron survey spectra analysis (XPS). Before each experiment, the thin films were first sputtered using $\mathrm{Ar}^{+}$ion for $1 \mathrm{~min}$ to remove possible surface contaminants. The $C$ is peak observed at $\sim 284.8 \mathrm{eV}$ was then used to evaluate its atomic content, while the $O$ 1s peak was assumed to be at $\sim 530.5 \mathrm{eV}$, and these peaks together with the $\mathrm{Ga} 2 \mathrm{p}_{3 / 2}$ peak at $\sim 1116.7 \mathrm{eV}$ were used to gauge the compositional ratio. Other atoms such as nitrogen $(1 \mathrm{~s}, 398.1 \mathrm{eV})$, fluorine (1s, $684.9 \mathrm{eV})$, and chlorine $\left(2 \mathrm{p}_{3 / 2}, 198.5 \mathrm{eV}\right)$ were not found in these XPS spectra, indicating low levels of these elements in the as-deposited thin films. The atomic compositions of the thin films, particularly the $\mathrm{O} / \mathrm{Ga}$ and $\mathrm{C} / \mathrm{G}$ a ratios calculated using sensitivity factors determined from the empirical peak area and then corrected for the system's transmission function, ${ }^{21}$ are also presented in Table 5. Moreover, the O/Ga atomi c ratio obtained by the XPS method seems to show a significant deviation from the ideal value of 1.5, which may be due to preferential sputtering or sputteringinduced decomposition. ${ }^{22}$ Corresponding measurements of content were then carried out using Rutherford backscattering analysis (RBS). This is because the basis of RBS lies in the energy profile of the $\mathrm{He}^{+}$ion beam that is backscattered from the target sample, which would not be seriously affected by the $\mathrm{Ar}^{+}$ion sputtering conducted prior to the typical XPS analysis. Figure 6 illustrates the RBS spectrum obtained for the respective thin film deposited at $500^{\circ} \mathrm{C}$. This shows not only the correct stoichiometry but also the absence of any thinfilm contaminant such as chlorine; the latter would give a peak with a leading edge at channel $\sim 1250$.

The $\mathrm{Ga}_{2} \mathrm{O}_{3}$ thin-film preparation was also extended to studies using the more volatile dimethylgallium complex $\mathbf{4}$ for the sake of comparison. Similar parameters were employed for these deposition experiments, except that the reservoir temperature was lowered to

(21) Wagner, C. D.; Davis, L. E.; Zeller, M. V.; Taylor, J . A.; Raymond, R. H.; Gale, L. H. Surf. Interface Ánal. 1981, 3, 211.

(22) J eong, J . I.; Moon, J . H.; Hong, J . H.; Kang, J .-S.; Fukuda, Y.; Lee, Y. P. J . Vac. Sci. Technol. A 1996, 14, 293. 
(a)

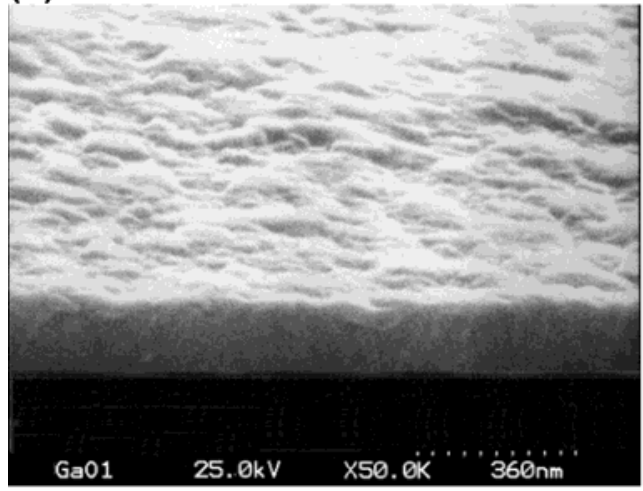

(c)

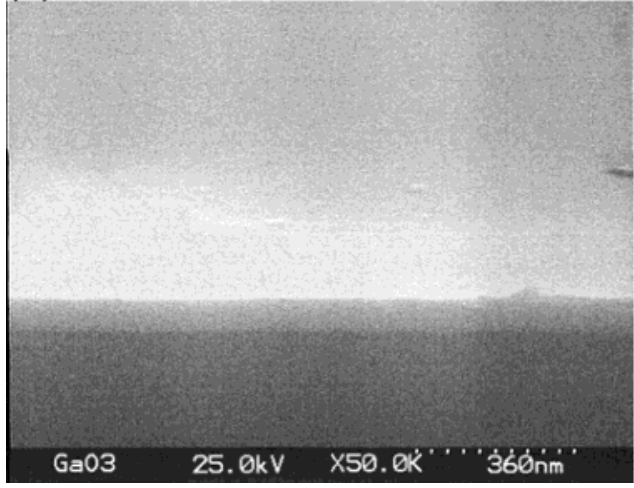

(b)

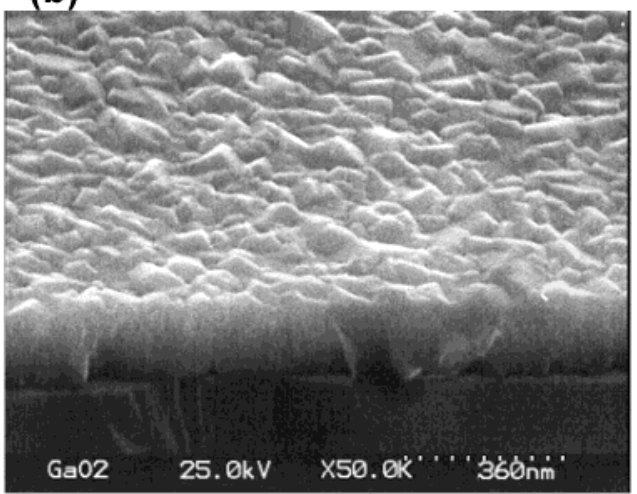

(d)

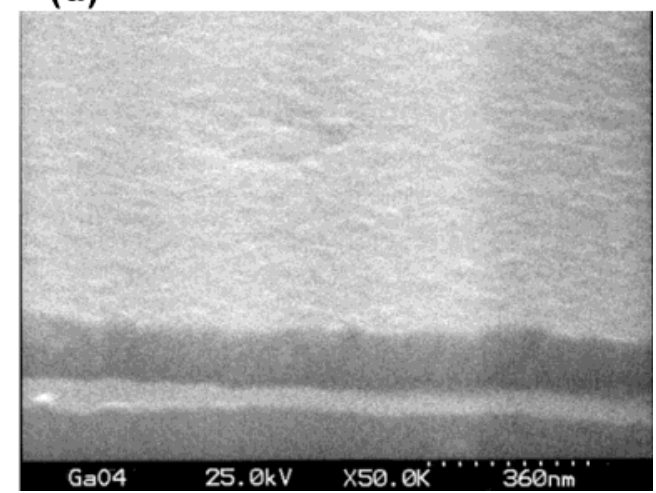

Figure 5. SEM micrographs of the $\mathrm{Ga}_{2} \mathrm{O}_{3}$ films with a $45^{\circ}$ view angle: (a) film 1; (b) film 2; (c) film 3; (d) film 4. The entry numbers are identical with those listed in Table 5.

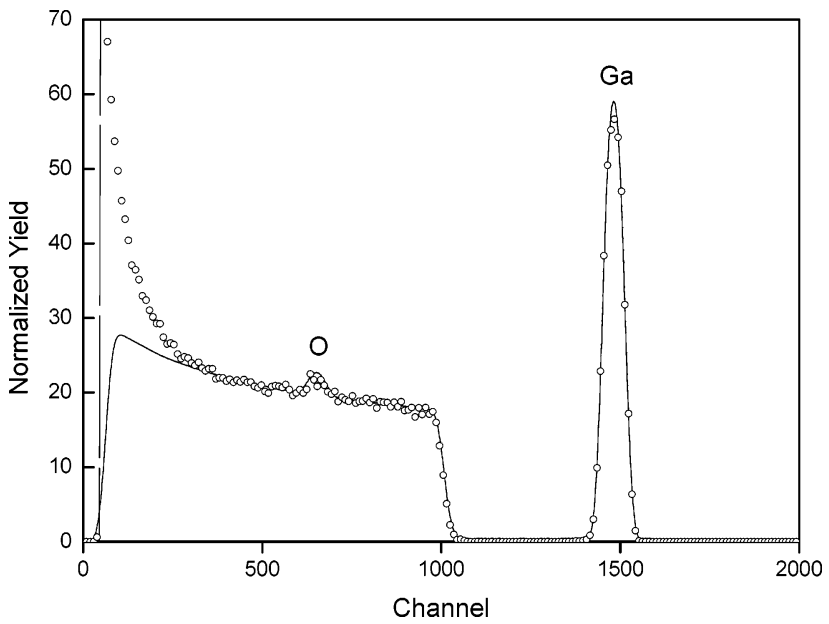

Figure 6. Rutherford backscattering of the $\mathrm{Ga}_{2} \mathrm{O}_{3}$ film deposited on an $\mathrm{Si}(100)$ substrate at $500^{\circ} \mathrm{C}$. Data fitting was carried out using RUMP simulation for an O/Ga ratio of $1.5 / 1$.

$45^{\circ} \mathrm{C}$ and the system pressure increased to 5 Torr. It seems that better $\mathrm{Ga}_{2} \mathrm{O}_{3}$ growth control was obtained in these studies, which showed a much smoother surface morphology (Figure $5 c, d$ ). All other physical characteristics such as composition and level of impurities are very similar to those deposited using complex $\mathbf{1}$ as the CVD source reagent.

\section{Discussion}

New types of aminoalkoxide gallium complexes $\mathbf{1}$ and 3-5 as well as the corresponding iminoal koxide complex $\mathbf{2}$ were prepared and characterized by routine spectro- scopic methods. Their structures reflect the number of the aminoalkoxide ligands incorporated into the molecule. F or the $\mathrm{GaCl}_{3}$ reactions, disubstitution occurred to afford the trigonal-bipyramidal complexes $\mathbf{1}$ and $\mathbf{2}$ with the remaining chloride ligand located at the equatorial positions. For comparison, the reaction of $\mathrm{GaCl}_{3}$ with chelating $\beta$-diketonates such as (hfac)Na and (tmhd)Na afforded the air-stable, trisubstituted complexes $\mathrm{Ga}(\mathrm{hfac})_{3}$ and $\mathrm{Ga}(\mathrm{tmhd})_{3}$ in high yields (hfac $=$ hexafluoroacetylacetonate and tmhd = tetramethylheptanedionate). ${ }^{23}$ This observation shows the marked difference in reactivity between the alkoxide ligands and the related $\beta$-diketonate chelates.

When the gallium reagent was changed from $\mathrm{GaCl}_{3}$ to $\mathrm{GaMe}_{3}$, the major products were the monosubstituted complexes $\mathrm{GaMe}_{2} \mathrm{~L}$, having a distinct tetrahedral geometry; disubstituted derivatives of the formula $\mathrm{GaL}_{2-}$ Me produced as side products were not isolated due to their air sensitivities. Moreover, in contrast to complexes $\mathbf{1}$ and 2, VT ${ }^{1} \mathrm{H}$ NMR studies showed that the tetrahedral complexes $\mathbf{3}$ and $\mathbf{4}$ with an asymmetrical amino functional group, i.e., $\mathrm{NHMe}$ and $\mathrm{NHBu}^{\mathrm{t}}$, underwent rapid isomerization via rupture of the $\mathrm{N} \rightarrow \mathrm{Ga}$ dative bond, followed by free rotation and recoordination with inversion of configuration at the nitrogen center. This rapid fluxional motion caused the methyl groups of the adjacent $\mathrm{GaMe}_{2}$ fragment to possess an averaged chemical environment, thus giving only one methyl resonance at the higher temperatures in the ${ }^{1} \mathrm{H}$ NMR spectra. Variation of the activation barrier was clearly

(23) Ballarin, B.; Battiston, G. A.; Benetollo, F.; Gerbasi, R.; Porchia, M.; Favretto, D.; Traldi, P. Inorg. Chim. Acta 1994, 217, 71. 
noted for complex $\mathbf{4}$ upon switching solvents, confirming an enhanced labilization effect of the bulky $\mathrm{Bu}^{\mathrm{t}}$ substituent.

For material applications, deposition of $\mathrm{Ga}_{2} \mathrm{O}_{3}$ by the MOCVD process is possible using the complexes $\mathbf{1}$ and 4; thin films deposited from complex 1 tended to possess much rougher surface morphology. Independent of the source reagent selected, all as-deposited films were fluorine and chlorine-free but showed small amounts of carbon impurities at a level of 3-5 atom \%, similar to that observed in $\mathrm{Ga}_{2} \mathrm{O}_{3}$ thin films deposited using the $\mathrm{Ga}(\mathrm{hfac})_{3}$ precursor ${ }^{24}$ The lack of fluorine and chl orine impurities can be explained by the formation of highly volatile species such as $\mathrm{GaF}_{3}$ and $\mathrm{GaCl}_{3}$ during the deposition. The high volatility of these materials allowed them to be effectively removed in the gas phase at the growth temperature, leaving the films free of this contamination. Moreover, our thin films remained essentially amor phous bel ow $600{ }^{\circ} \mathrm{C}$ and slowly converted into a highly crystalline phase after thermal treatment at $900{ }^{\circ} \mathrm{C}$ under an $\mathrm{O}_{2}$ atmosphere. On the basis of these observed properties, we anticipated that both complexes $\mathbf{1}$ and $\mathbf{4}$ would be suitable for the deposition of $\mathrm{Ga}_{2} \mathrm{O}_{3}$ thin films. For comparison, the commercially available alkyl complexes $\mathrm{GaMe}_{3}$ and $\mathrm{GaEt}_{3}$ are also good CVD

(24) Battiston, G. A.; Gerbasi, R.; Porchia, M.; Bertoncello, R.; Caccavale, F. Thin Solid Films 1996, 279, 115. source reagents for depositing gallium oxide films, but their pyrophoric nature makes the storage and handling significantly more difficult than for our Ga source complexes. On the other hand, the multistep synthesis required for the amino al cohol and imino al cohol ligands makes our $\mathrm{Ga}$ complexes somewhat less suitable for future scale-up operation, compared with other nonfluorinated alkoxide reagents such as $\mathrm{Ga}\left(\mathrm{OPr}^{\mathrm{i}}\right)_{3}{ }^{1}$ and the $\beta$-diketonate complex $\mathrm{Ga}(\mathrm{dpm})_{3}$ (dpm = dipivaloylmethanate); the latter was successfully used for the preparation of $\mathrm{PrGaO}_{3}$ film in superconducting electronics. ${ }^{25}$

Acknowledgment. Y.C. thanks the National Science Council for financial support (NSC Grant Nos. 912113-M-007-047 and NSC 92-2113-M-007-036), and A.J .C. is grateful to the National Research Council of Canada for funding of this research.

Supporting Information Available: Tables giving X-ray structural data for complexes $\mathbf{1}, \mathbf{2}$, and $\mathbf{5}$ and a figure showingTGA data for complexes $\mathbf{1}$ and $\mathbf{3}-\mathbf{5}$. This material is available free of charge via the Internet at http://pubs.acs.org.

OM034148D

(25) Han, B.; Neumayer, D. A.; Schulz, D. L.; Hinds, B. J .; Marks, T. J. J. Vac. Sci. Technol. A 1993, 11, 1431. 